Article

\title{
Growth Trends of Coniferous Species along Elevational Transects in the Central European Alps Indicate Decreasing Sensitivity to Climate Warming
}

\author{
Walter Oberhuber ${ }^{1}{ }^{1}$, Ursula Bendler ${ }^{1}$, Vanessa Gamper ${ }^{1}$, Jacob Geier ${ }^{1}$, Anna Hölzl ${ }^{1}$, \\ Werner Kofler ${ }^{1}$, Hanna Krismer ${ }^{2}$, Barbara Waldboth ${ }^{1}$ and Gerhard Wieser ${ }^{3, *(D)}$ \\ 1 Department of Botany, Leopold-Franzens-Universität Innsbruck, Sternwartestraße 15, \\ A-6020 Innsbruck, Austria; walter.oberhuber@uibk.ac.at (W.O.); ursula.bendler@student.uibk.ac.at (U.B.); \\ vanessa.gamper@student.uibk.ac.at (V.G.); jacob.geier@student.uibk.ac.at (J.G.); \\ anna.hoelzl111@gmail.com (A.H.); werner.kofler@uibk.ac.at (W.K.); \\ barbara.waldboth@student.uibk.ac.at (B.W.) \\ 2 Department of Forest-and Soil Sciences, Institute of Silviculture, University of Natural Resources and Life \\ Sciences, Peter-Jordan-Straße 82, A-1190 Vienna, Austria; hanna.krismer@tirol.gv.at \\ 3 Division of Alpine Timberline Ecophysiology, Federal Research and Training Centre for Forests, \\ Natural Hazards and Landscape (BFW), Rennweg 1, A-6020 Innsbruck, Austria \\ * Correspondence: gerhard.wieser@uibk.ac.at; Tel.: +43-512-5739-335120
}

Received: 21 November 2019; Accepted: 20 January 2020; Published: 22 January 2020

\begin{abstract}
Tree growth at high elevation in the Central European Alps (CEA) is strongly limited by low temperature during the growing season. We developed a tree ring series of co-occurring conifers (Swiss stone pine, Norway spruce, European larch) along elevational transects stretching from the subalpine zone to the krummholz limit (1630-2290 m asl; $n=503$ trees) and evaluated whether trends in basal area increment (BAI) are in line with two phases of climate warming, which occurred from 1915-1953 and from 1975-2015. Unexpectedly, results revealed that at subalpine sites (i) intensified climate warming in recent decades did not lead to a corresponding increase in BAI and (ii) increase in summer temperature since 1915 primarily favored growth of larch and spruce, although Swiss stone pine dominates at high elevations in the Eastern CEA, and therefore was expected to mainly benefit from climate warming. At treeline, BAI increases in all species were above the level expected based on determined age trend, whereas at the krummholz limit only deciduous larch showed a minor growth increase. We explain missing adequate growth response to recent climate warming by strengthened competition for resources (nutrients, light, water) in increasingly denser stands at subalpine sites, and by frost desiccation injuries of evergreen tree species at the krummholz limit. To conclude, accurate forecasts of tree growth response to climate warming at high elevation must consider changes in stand density as well as species-specific sensitivity to climate variables beyond the growing season.
\end{abstract}

Keywords: elevational transect; basal area increment; climate warming; conifers; European Alps; growth trend

\section{Introduction}

It is well established that tree growth at high elevation and in boreal regions is mainly temperature-limited [1-4] and temperatures below $5{ }^{\circ} \mathrm{C}$ during the growing season impair tissue formation in woody plants $[5,6]$. Consistently, numerous dendroclimatological studies have revealed that radial stem growth in the Central European Alps (CEA) is limited by low summer temperature e.g., $[7,8]$. Climate observations reveal a rise of air temperature in recent decades and global change 
models predict even further temperature increases in the future [9]. This phenomenon is especially pronounced in the European Alps, showing almost twice increase of air temperature compared to the global rate $[10,11]$. Although climate warming was found to increase radial growth at high elevation and in boreal regions [12], radial growth did not consistently track recent temperature increase [13].

A low-frequency offset between radial tree growth that does not correspond to the increase in summer temperatures is known as a divergence problem [14]. Although in the European Alps no unusual late 20th century divergence problem was found by [12], several authors [15,16] have found that recent temperature increase had a negative effect on tree growth at high elevation. Similarly, [13] reported a loss of sensitivity of temperature-limited temperate and boreal tree-ring series starting in the latter half of the 20th century. Understanding the growth response of high elevation forests to climate warming is of great importance because forests are a major part of the global carbon cycle and significant alterations are expected in upcoming decades, see [17] and further references therein.

Several authors have encouraged the application of large-scale dendroclimatological studies to assess tree growth response to atmospheric changes [18]. However, at the local scale tree growth could be biased by nonclimatic factors like resource availability (soil nutrients, water, light) and topography [19-22]. Therefore, to evaluate tree growth response in CEA to climate warming since the early 20th century, we used a recently acquired collection of tree-ring width data from 503 trees distributed at several elevational transects across the subalpine zone, treeline, and krummholz limit. Radial growth measurements were converted to basal area increments (BAI), aggregated according to elevation (subalpine, treeline, and krummholz limit), and resulting BAI time series were compared with homogenized climate data from representative instrumental stations of the CEA.

Instrumental temperature records show two phases of climate warming from early to mid-20th century and from mid-1970s until 2015 [10], which are also evident on larger geographic scales $[9,13,23-25]$. We therefore focused on elevational-dependent changes in radial growth trends of the three dominant coniferous tree species in the Eastern CEA, i.e., Norway spruce (Picea abies [L. Karst.] L.), European larch (Larix decidua Mill.), and Swiss stone pine (Pinus cembra L.), and evaluated whether the observed growth trends in BAI are consistent with the increase in summer air temperature over these two phases of climate warming. We expected that BAI of all species, but especially P. cembra, which is the dominant conifer at high elevation within the study area, would show increasing BAI consistent with distinct climate warming during the study period (1915-2015) amounting to $>2{ }^{\circ} \mathrm{C}$.

\section{Material and Methods}

\subsection{Study Sites}

The study sites are located along the Eastern CEA (Table 1) in the area of the Tuxer and Stubaier Alps (Tyrol, Austria) and Ötztaler Alps (border area of Austria and Italy) and encompass elevational transects including the subalpine zone (1630-2290 m asl), treeline (1950-2130 m asl) and the krummholz-limit (2130-2270 $\mathrm{m}$ asl). Treeline and the krummholz-limit are defined as uppermost patches of trees of at least $2 \mathrm{~m}$ height, and crippled individuals occurring above treeline and less than $2 \mathrm{~m}$ in height, respectively. Although most continental climate conditions enable subalpine forests to reach highest elevations at sites SCH1 and SCH2 (Table 1), anthropogenic influence (pasturing) impairs development of a natural treeline and krummholz-limit. Selected tree species include European larch (Larix decidua), Norway spruce (Picea abies) and Swiss stone pine (Pinus cembra), which are the dominant and widespread tree species at high elevation in the Eastern CEA [26]. 
Table 1. Site characteristics of selected stands along elevational transects in the Central European Alps. Geographic coordinates are given for the lowest site at each sampled transect (Lat = latitude; Lon = longitude; $\Delta \mathrm{E}=$ elevational difference between highest and lowest stand).

\begin{tabular}{|c|c|c|c|c|c|c|c|c|}
\hline \multicolumn{9}{|c|}{ Elevation ( $\mathrm{m}$ asl) } \\
\hline Site & Lat & Lon & Subalpine & Treeline & Krummholz & (m) & Aspect & Slope $\left({ }^{\circ}\right)$ \\
\hline $\begin{array}{l}\text { Patscherkofel } \\
\text { (PTK) }\end{array}$ & 47.206 & 11.452 & 1960-2010 & 2080-2130 & $2140-2180$ & 220 & WSW-W & $10-30$ \\
\hline $\begin{array}{c}\text { Viggarspitze } \\
\text { (VIG) }\end{array}$ & 47.213 & 11.480 & $2030-2050$ & $2120-2060$ & $2220-2270$ & 240 & SSW & $10-40$ \\
\hline $\begin{array}{l}\text { Morgenköpfl } \\
\text { (MOR) }\end{array}$ & 47.179 & 11.469 & 1880-2020 & $2060-2120$ & $2130-2220$ & 340 & SW-NW & $10-30$ \\
\hline $\begin{array}{l}\text { Kaserstattalm } \\
\text { (KAS) }\end{array}$ & 47.115 & 11.290 & $1640-1800$ & 1950-1990 & - & 350 & SE-SW & $20-30$ \\
\hline Elferlift (ELF) & 47.096 & 11.305 & 1630-1810 & - & - & 180 & NW-NE & $20-30$ \\
\hline $\begin{array}{l}\text { Lazauntal } \\
\text { (SCH1) }\end{array}$ & 46.756 & 10.779 & $2040-2290$ & - & - & 250 & E & $30-45$ \\
\hline $\begin{array}{l}\text { Finailtal } \\
\text { (SCH2) }\end{array}$ & 46.743 & 10.827 & $2120-2250$ & - & - & 130 & W & $30-50$ \\
\hline
\end{tabular}

Within the Eastern CEA, the geology of the Tuxer and Ötztaler Alps is dominated by siliceous parent material. In the Stubaier Alps, the bedrock at selected sites (Elferlifte, Kaserstattalm) is of calcareous origin [27]. Local disturbance at some sites (primarily above the edge of the closed subalpine forest, i.e., at treeline and the krummholz limit) is restricted to grazing. Annual/summer temperature means and annual/summer precipitation totals during the study period 1915-2015 amounted to $0.5 / 7.7^{\circ} \mathrm{C}$ and $1133 / 433 \mathrm{~mm}$, respectively [10].

\subsection{Tree-Ring Analysis}

A uniform sampling design was applied at all selected sites. Along elevational transects, two radii per tree were obtained from opposite sides of the stem using an increment borer. Trees free of major stem or crown anomalies due to wind or snow breakage were randomly selected and cored parallel to the contour to avoid biases induced by formation of reaction wood. At subalpine sites, cores were extracted from dominant mature trees at breast height $(1.3 \mathrm{~m})$. Due to a decrease in tree height towards higher elevation, cores were taken between $0.5 \mathrm{~m}$ and $0.2 \mathrm{~m}$ height at treeline and the krummholz limit, respectively ( $n=503$ trees; Table 2$)$.

Table 2. Age structure and sample depth of selected stands along elevational transects (mean age (year) \pm standard deviation (SD)/n sampled trees). Abbreviations of sites as in Table 1 ; Pice $=$ Pinus cembra L., Lade = Larix decidua, Pcab = Picea abies L. Karst.

\begin{tabular}{|c|c|c|c|c|c|c|c|c|c|}
\hline & \multicolumn{3}{|c|}{ Subalpine } & \multicolumn{3}{|c|}{ Treeline } & \multicolumn{3}{|c|}{ Krummholz-Limit } \\
\hline & Pice & Lade & $P c a b$ & Pice & Lade & Pcab & Pice & Lade & Pcab \\
\hline PTK & $124 \pm 43 / 8$ & $133 \pm 45 / 5$ & $146 \pm 38 / 10$ & $37 \pm 15 / 15$ & $32 \pm 19 / 14$ & $26 \pm 18 / 13$ & $15 \pm 5 / 10$ & $12 \pm 3 / 10$ & $23 \pm 17 / 10$ \\
\hline VIG & $138 \pm 39 / 8$ & $128 \pm 28 / 6$ & $85 \pm 11 / 5$ & $22 \pm 7 / 10$ & $29 \pm 17 / 11$ & - & $14 \pm 4 / 9$ & $10 \pm 3 / 12$ & - \\
\hline MOR & $118 \pm 6 / 10$ & $103 \pm 12 / 10$ & - & $25 \pm 7 / 11$ & $31 \pm 20 / 13$ & - & $17 \pm 3 / 9$ & $17 \pm 5 / 12$ & - \\
\hline KAS & - & $133 \pm 23 / 10$ & $142 \pm 23 / 24$ & $14 \pm 3 / 53$ & $18 \pm 4 / 51$ & $16 \pm 4 / 46$ & - & - & - \\
\hline ELF & - & $175 \pm 47 / 25$ & $150 \pm 43 / 35$ & - & - & - & - & - & - \\
\hline SCH1 & $270 \pm 54 / 24$ & - & - & - & - & - & - & - & - \\
\hline $\mathrm{SCH} 2$ & - & $128 \pm 35 / 14$ & - & - & - & - & - & - & - \\
\hline mean $\pm S D$ & $199 \pm 42$ & $133 \pm 32$ & $131 \pm 29$ & $25 \pm 8$ & $27 \pm 15$ & $21 \pm 11$ & $15 \pm 4$ & $13 \pm 4$ & $23 \pm 17$ \\
\hline$n$ total & 50 & 70 & 74 & 89 & 89 & 59 & 28 & 34 & 10 \\
\hline
\end{tabular}

Increment cores were air-dried, mounted on wooden holders, and the surface was prepared with a razor blade. For contrast enhancement of tree-ring boundaries, white chalk powder was rubbed into the tracheid lumen. Ring widths were measured to the nearest $1 \mu \mathrm{m}$ using a light microscope (Olympus SZ61, Tokyo, Japan) fitted with a LINTAB measuring system (Frank Rinn, Heidelberg, Germany). Correct dating of measured time series of ring width were statistically checked with the TSAP-Win 
Scientific and COFECHA [28] software and mean tree-ring width chronologies were developed for each site and species.

Correctly dated tree-ring width chronologies were converted into basal area increment (BAI) values excluding the bark and assuming a circular shape of the stem with the following formula:

$$
B A I=\pi\left(R_{n}^{2}-R^{2}{ }_{n-1}\right),
$$

where $R$ is the radius of the tree inside the bark and $n$ is the year of tree ring formation. Bark thickness and stem diameter at coring height were measured at the time of sampling. BAI data were not standardized to preserve the long-term growth trend over the study period. BAI instead of ring-width time series were chosen because BAI is more closely related to biomass increment than ring width and BAI reduces tree size and age effects on growth trends [18,29-31].

To be able to distinguish climate warming-induced growth increases from inherent age/size related growth trends, species-specific biological growth curves were developed by aligning annual increments of individual trees to the biological (cambial) age instead of the calendar year and calculating age/size-related growth trends by fitting linear functions to the data [31]. Number of missing rings, to the pith in the increment cores, were estimated via the curvature and width of the inner rings. Species-specific age/size related trends in BAI were then plotted in a BAI time series developed at treeline and krummholz limit (mean tree age $<30$ years Table 2). At treeline and the krummholz limit, radial growth of saplings may be strongly restricted for numerous years due to pronounced competition with dwarf shrubs and grasses for nutrients and light. As soon as saplings are well established, radial growth distinctly increases [32]. The onset of the expected age/size-related growth trend was scheduled to that specific year. We are aware that this dating occurred somewhat arbitrarily, but a change in timing by \pm 2 years has no crucial effect on data interpretation.

\subsection{Climate Data}

Mean summer (June through August) and yearly temperature $\left({ }^{\circ} \mathrm{C}\right)$ and precipitation $(\mathrm{mm})$ data for the Greater Alpine Region (Histalp_region AT-West and HighLevel) were obtained from the HISTALP database (http://www.zamg.ac.at/histalp/) [10]. Climate data are mean monthly temperature and precipitation sums collected from several sites located at high (mean elevation $2091 \mathrm{~m}$ asl) and low elevation (mean elevation 773 mThis is o.k. asl), respectively, which are representative for the study region. During the last one hundred years, two phases of climate warming, i.e., from 1915-1953 ( $\left.\mathrm{W}_{\mathrm{ph}} \mathrm{I}\right)$ and from 1975-2015 ( $\left.\mathrm{W}_{\mathrm{ph}} \mathrm{II}\right)$ are obvious in climate records (Figure 1). Mean temperature during 5 -year-long periods at the start and end of these phases were calculated. Additionally, temperature difference between start and end of the study period (1915-2015; $\left.\mathrm{W}_{\mathrm{ph}} \mathrm{III}\right)$ was determined based on selected 5-year means (Figure 1). 


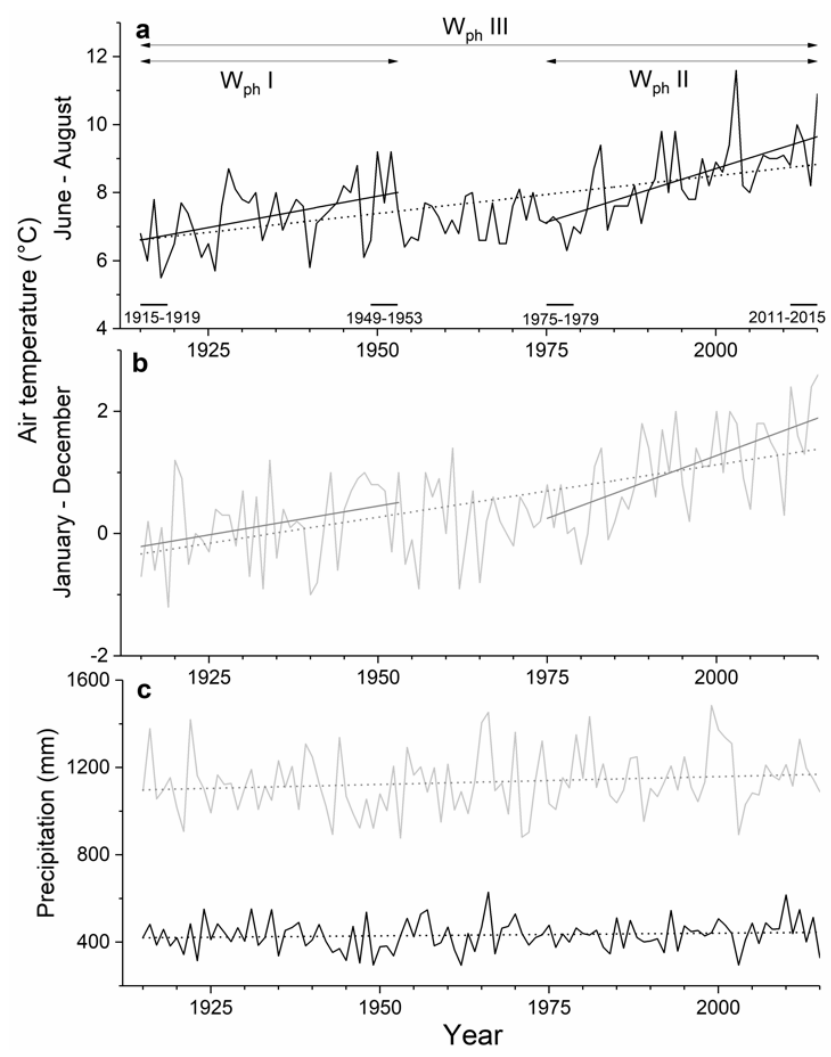

Figure 1. Mean air temperature (a,b) and precipitation (c) during June-August (black lines) and January-December (grey lines) in the Alpine region for the period 1915-2015. In (a), increase in air temperature was divided into two phases: phase $\mathrm{I}\left(\mathrm{W}_{\mathrm{ph}} \mathrm{I}\right)$ from 1915-1953 and phase II ( $\left.\mathrm{W}_{\mathrm{ph}} \mathrm{II}\right)$ from 1975-2015. Period III ( $\left.W_{\mathrm{ph}} \mathrm{III}\right)$ encompasses the whole study period 1915-2015. Linear air temperature and precipitation trends are shown in solid lines for $\mathrm{W}_{\mathrm{ph}} \mathrm{I}$ and $\mathrm{W}_{\mathrm{ph}} \mathrm{II}$ and dotted lines for $\mathrm{W}_{\mathrm{ph}} \mathrm{III}$. Five-year periods used to calculate mean values of air temperature and basal area increment during selected periods $\left(\mathrm{W}_{\mathrm{ph}} \mathrm{I}-\mathrm{III}\right)$ are indicated.

\subsection{Statistical Analysis}

Student's independent sample $t$-test was used to determine significant differences among selected time periods with respect to air temperature and BAI. Homogeneity of variances was asserted using Levene's test. Age trends in BAI time series were fit by linear regression analysis. All tests were performed using STATISTICA 12 (StatSoft Inc., Tulsa, OK, USA).

\section{Results}

During the study period 1915-2015 yearly (January-December) and summer (June-August) air temperatures showed an increasing trend, which intensified since the late 1970s (Figure 1). During the selected warming phases, WphI and WphII, yearly/summer air temperature increased by $+1.04 /+1.7^{\circ} \mathrm{C}$ and $+1.62 /+2.52^{\circ} \mathrm{C}$, respectively, indicating accelerated climate warming in recent decades (Figure 2 ). 


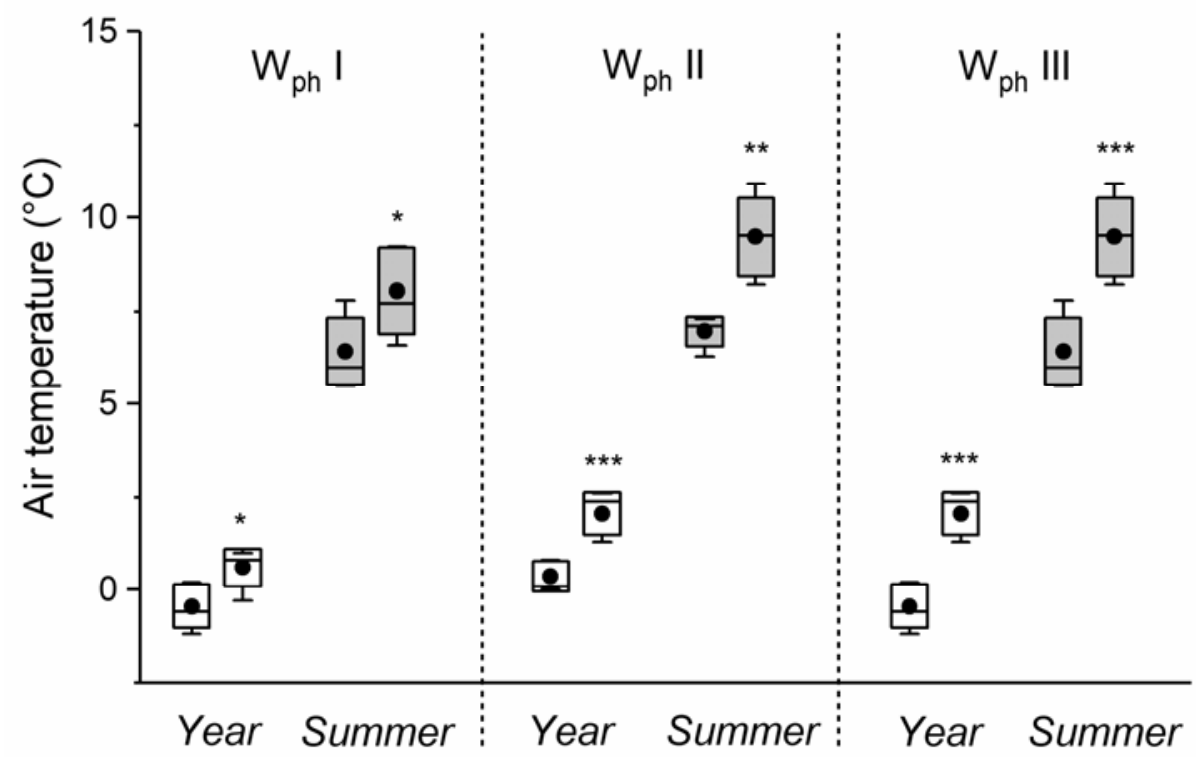

Figure 2. Comparison of yearly and summer (June-August) air temperatures between the beginning and end of phase $\mathrm{I}\left(\mathrm{W}_{\mathrm{ph}} \mathrm{I}\right)$, phase $\mathrm{II}\left(\mathrm{W}_{\mathrm{ph}} \mathrm{II}\right)$, and during the whole study period, i.e., beginning of phase I and end of phase II ( $\mathrm{W}_{\mathrm{ph}} \mathrm{III}$; cf. Figure 1). A box and whiskers plot shows the median (horizontal line) and mean values (closed circle) \pm standard deviation (box); whiskers extend to the 10th and 90th percentiles. Statistical significant differences between mean temperatures at the beginning and end of the warming phases are indicated by asterisks $\left({ }^{*} p \leq 0.05,{ }^{* *} p \leq 0.01,{ }^{* * *} p \leq 0.001\right)$.

Comparing the first (1915-1919) and last (2011-2015) five-year mean values, yearly and summer air temperature increased by $+2.5^{\circ} \mathrm{C}$ and $+3.1^{\circ} \mathrm{C}$, respectively (Figure 3). In contrast, yearly and summer precipitation showed a slight but statistically not significant increase $(p>0.05)$ over the whole study period (Figure 1c).

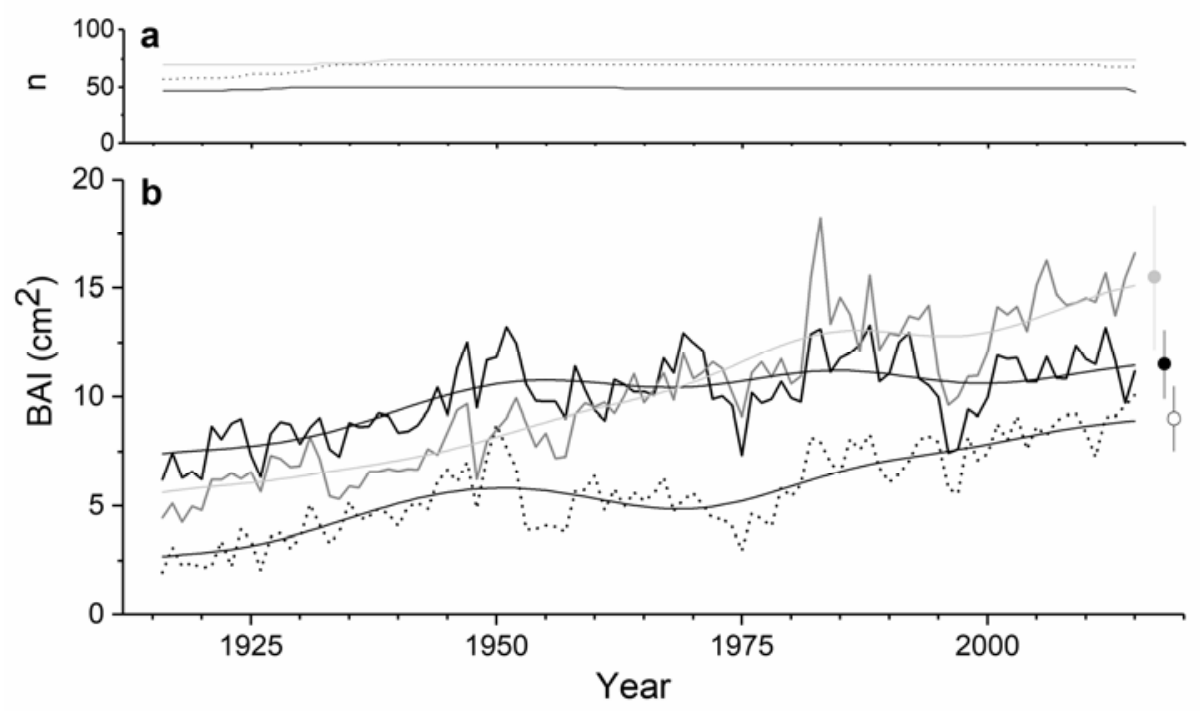

Figure 3. Sample depth (a) and basal area increment (BAI; b) of selected tree species from subalpine sites (Pinus cembra = continuous black line; Picea abies = continuous grey line; Larix decidua = dotted black line). Data were smoothed based on a fast Fourier transform low-pass filter (thin lines; number of points set to 10). Mean values \pm standard error are indicated.

In the subalpine zone, mean age of all tree species at coring height was $>130$ years, whereas at treeline and at the krummholz limit mean age of tree species averaged to $c .25$ and c. 17 years, 
respectively (Table 2). Mean stem diameter of P. cembra, L. decidua, and P. abies decreased from $40 \pm 7 \mathrm{~cm}$, $38 \pm 8 \mathrm{~cm}$, and $39 \pm 6 \mathrm{~cm}$ in the subalpine zone, to $11 \pm 3 \mathrm{~cm}, 11 \pm 3 \mathrm{~cm}$, and $10 \pm 2 \mathrm{~cm}$ at the treeline, and $5 \pm 1 \mathrm{~cm}, 5 \pm 1 \mathrm{~cm}$, and $4 \pm 1 \mathrm{~cm}$ at the krummholz limit, respectively.

The number of trees included in the mean BAI stayed nearly constant during the study period 1915-2015 (Figure 3a). Increasing growth is obvious in all species during $\mathrm{W}_{\mathrm{ph}} \mathrm{I}$. Afterwards, growth of $P$. cembra increased at a lower rate, while BAI of P. abies and L. decidua also strongly increased during the second warming phase ( $\mathrm{W}_{\mathrm{ph}} \mathrm{II}$; Figures $3 \mathrm{~b}$ and 4$)$.

Although BAI increase of all species was statistically significant in $\mathrm{W}_{\mathrm{ph}} \mathrm{I}$-III (Figure 4), BAI increase significantly declined during $\mathrm{W}_{\mathrm{ph}} \mathrm{II}$ compared to $\mathrm{W}_{\mathrm{ph}} \mathrm{I}$ in P. cembra, and remained constant in L. decidua and P. abies (Table 3). During the whole study period (1915-2015, $\left.\mathrm{W}_{\mathrm{ph}} \mathrm{III}\right)$ BAI increase was highest in $P$. abies and lowest in P. cembra (Table 3).

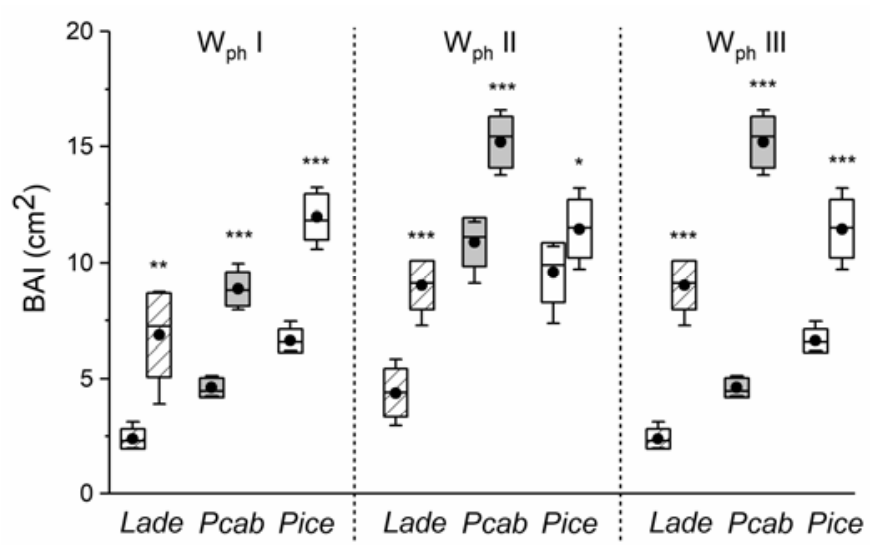

Figure 4. Comparison of mean basal area increment (BAI) of selected tree species (Lade = Larix decidua; Pcab = Picea abies; Pice $=$ Pinus cembra $)$ from subalpine sites at beginning and end of increasing air temperature during phase $\mathrm{I}\left(\mathrm{W}_{\mathrm{ph}} \mathrm{I}\right)$, phase II $\left(\mathrm{W}_{\mathrm{ph}} \mathrm{II}\right)$ and during the whole study period $\left(\mathrm{W}_{\mathrm{ph}} \mathrm{III}\right.$; cf. Figure 1). Box and whiskers plot showing median (horizontal line) and mean (closed circle) \pm standard deviation (box); whiskers extend to the 10th and 90th percentiles. Statistical significant differences between BAI at the beginning and end of warming phases are indicated by asterisks $\left({ }^{*} p \leq 0.05\right.$, ** $\left.p \leq 0.01,{ }^{* * *} p \leq 0.001\right)$.

Table 3. Increase in basal area increment $\left(\mathrm{cm}^{2}\right)$ during selected phases of climate warming $\left(\mathrm{W}_{\mathrm{ph}} \mathrm{I}-\mathrm{III}\right)$. Mean values \pm standard deviations are shown. Statistically significant differences of mean values between species and $\mathrm{W}_{\mathrm{ph}} \mathrm{I}$ and $\mathrm{W}_{\mathrm{ph}} \mathrm{II}$ are indicated by different letters $(p \leq 0.05)$.

\begin{tabular}{cccc}
\hline Species & $\mathbf{W}_{\mathbf{p h}} \mathbf{I}$ & $\mathbf{W}_{\mathbf{p h}} \mathbf{I I}$ & $\mathbf{W}_{\mathbf{p h}} \mathbf{I I I}$ \\
\hline Pinus cembra & $5.35 \pm 0.84^{\mathrm{a}}$ & $1.89 \pm 1.78^{\mathrm{b}}$ & $4.84 \pm 1.33^{\mathrm{a}}$ \\
Larix decidua & $4.49 \pm 1.91^{\mathrm{a}}$ & $4.65 \pm 0.54^{\mathrm{a}}$ & $6.66 \pm 1.05^{\mathrm{b}}$ \\
Picea abies & $4.24 \pm 0.82^{\mathrm{a}}$ & $4.28 \pm 1.23^{\mathrm{a}}$ & $10.57 \pm 1.22^{\mathrm{c}}$ \\
\hline
\end{tabular}

When BAI is plotted against cambial age, age/size trends become obvious (Figure 5). In the first few decades of juvenile growth BAI shows a linear increase. Linear functions fitted to BAI of juvenile growth indicate that developed age/size trends extend up to c. 40 years in P. cembra and L. decidua and c. 35 years in P. abies. Slopes of the regression lines indicate that juvenile growth was highest and lowest in P. cembra and L. decidua, respectively. BAI increase during the last decade is clearly above the determined age trend in each species at treeline (Figure 6), but at the krummholz limit BAI increase was higher than the expected age trend in some years in L. decidua only (Figure 6). 


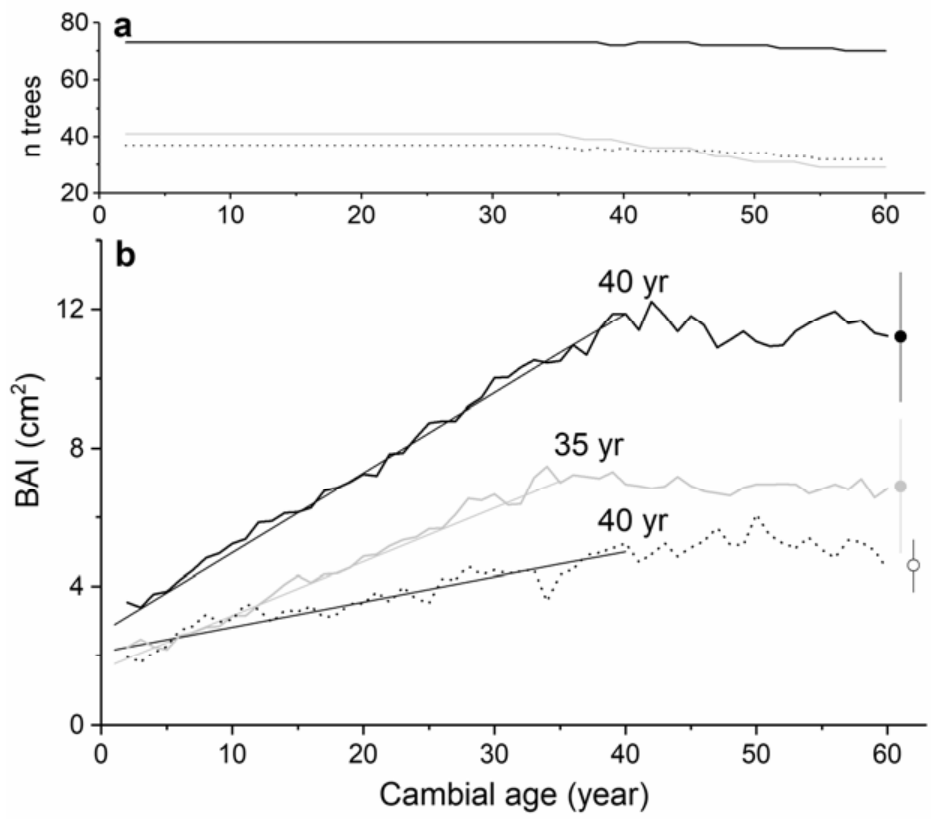

Figure 5. Sample depth (a) and basal area increment (BAI; b) of selected tree species from subalpine sites at cambial age 1-60 years (Pinus cembra = continuous black line; Picea abies = continuous grey line; Larix decidua $=$ dotted black line). Variance among samples are indicated by mean standard error. Age trends were fit by linear regression analysis and are indicated by thin lines. Pinus cembra: $y=0.224 \mathrm{x}+$ 2.897, $R^{2}=0.995 ;$ Picea abies: $\mathrm{y}=0.151 \mathrm{x}+1.762, R^{2}=0.975 ;$ Larix decidua: $\mathrm{y}=0.071 \mathrm{x}+2.165, R^{2}=0.877$.
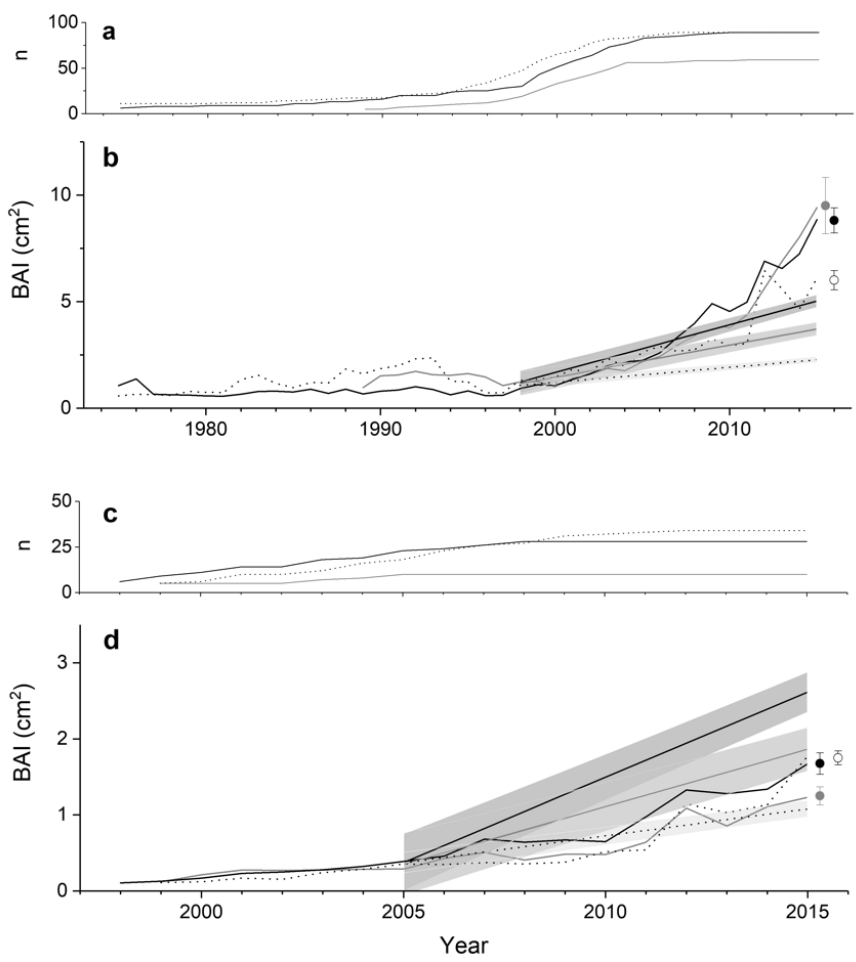

Figure 6. Sample depth and basal area increment (BAI) of tree species at treeline $(\mathbf{a}, \mathbf{b})$ and krummholz limit (c,d). Pinus cembra = continuous black line; Picea abies = continuous grey line; Larix decidua = dotted black line. Variance among samples is indicated by mean standard error. Species-specific age trends in BAI were plotted based on regression equations given in Figure 5. 95\% confidence intervals are indicated. Onset of age trend in BAI was assumed to occur at the time when continuous growth increase was detected (for details see Materials and Methods). 


\section{Discussion}

To strengthen the common climate signal and cancel out the local nonclimate signals, such as disturbance and topography, we pooled growth data ( $n=503$ trees) from several high-elevation forest sites. Long-term growth trends in the subalpine zone (1630-2290 m asl) revealed a dominating increase in BAI of mature forests (mean age >130 years) from 1915-2015, which is consistent with intense climate warming within the CEA [10]. However, results revealed stable BAI increase in the subalpine zone during $\mathrm{W}_{\mathrm{ph}} \mathrm{I}$ and $\mathrm{W}_{\mathrm{ph}} \mathrm{II}$ in L. decidua and P. abies, and decreasing BAI increase in P. cembra, although climate warming was much more distinct during the recent period $\left(+1.6{ }^{\circ} \mathrm{C}\right.$ in $\mathrm{W}_{\mathrm{ph}} \mathrm{I}$ vs. $+2.5^{\circ} \mathrm{C}$ in $\mathrm{W}_{\mathrm{ph}} \mathrm{II}$ during June through August, i.e., the main growing period; Figure 2). Age/size trends are not a conclusive explanation for this finding, because c. $90 \%$ of age/size related BAI increase is reached when trees are c. 30 years old (Figure 4), indicating that age/size effects are only marginally involved in BAI increase during $W_{\mathrm{ph}} \mathrm{I}$. As suggested by [33], the strong increase in wood increment in the early 20th century in the Eastern CEA is partly attributable to changes in forest management, i.e., reduction or abandonment of forest grazing, pollarding, or litter raking. Although we cannot refute changing land-use practices during $\mathrm{W}_{\mathrm{ph}} \mathrm{I}$ on $\mathrm{BAI}$, it is reasonable to assume that forest management practices were less pronounced on steep slopes at high elevation, which prevail within the study area (Table 1).

A loss of thermal response of radial tree growth in recent decades has been reported for P. cembra from one site within the study area on Mt. Patscherkofel [15] and from other temperature-limited sites $[13,16]$. Several hypotheses have been put forward to explain the missing adequate growth response of temperature-limited trees to recent climate warming [13,14], but the exact cause is still unknown. Several authors [15,34,35] attributed reduced radial growth in the European Alps to late-summer drought under increasing temperature. There is evidence that warm-season vapor pressure deficit and maximum daily temperature are closely related to forest drought stress [36]. Within the study area, however, increasing moisture stress in concordance with higher temperature is unlikely, because ample precipitation and moderate evaporative demand are regarded to cause soil water availability to be sufficiently high throughout the growing season [37]. Furthermore, although summer warming in the study region has been most prominent since late 1970s, it was not accompanied by a drying trend with decreased precipitation (Figure 1c). Missing matches between summer temperature increase and radial growth might be due to sensitivity of radial growth to several other climate parameters, such as previous autumn temperature and winter precipitation $[8,35,38,39]$, which might partly compensate for more favorable growing conditions during summer. Alternatively, stand dynamics might cause increasing competition among trees for light and nutrients, which leads to decreasing sensitivity of growth to climate warming [40]. In the subalpine zone, lowest sensitivity to recent climate warming was found in late successional P. cembra showing highest mean age. Although tree age effects on growth response to climate was reported by [41,42], [35] reported that the climate signal in P. cembra is maximized in older trees and [43] found little evidence for decreasing climate sensitivity in old P. cembra, indicating that tree age per se is not the cause of reduced temperature sensitivity in this species.

Sampling issues were also reported to seriously affect growth trend evaluation [44-46]. A common sampling bias in dendrochronology is the 'big tree selection bias', i.e., time series are constructed from similar sized large trees of different ages [45,47]. This sampling design can lead to misleading estimates of growth trends within a stand [48]. We avoided this bias by evaluating growth trends only throughout periods with constant sample depth, i.e., BAI time series were developed from trees of comparable age rather than size. Another potential sampling bias is the 'slow-grower survivorship bias', i.e., an underrepresentation of fast-growing trees in the earlier portion of the developed time series, which yields to an apparent increase in growth over time. Due to the fact that only living trees were sampled in this study, we cannot unequivocally exclude the occurrence of this bias in our data set. However, considering this bias would lead to higher BAI in earlier parts of the record, causing a decrease in growth response to climate warming during $\mathrm{W}_{\mathrm{ph}} \mathrm{I}$ and the whole study period (1915-2015; $\mathrm{W}_{\mathrm{ph}}$ III). 
Of the three selected species, most distinct growth response to climate warming was expected for P. cembra, which dominates at highest elevations in the Eastern CEA [26]. However, in the subalpine zone the largest growth increase over the whole study period was detected in P. abies (Table 3), suggesting that elevation may be associated with other environmental factors in addition to temperature [49] or that in old-growth P. cembra stands the benefit to growth brought on by a longer growing season may have been low in comparison with some other factors, such as the increasing respiration losses caused by warmer summer temperatures. However, the latter argument is contradicted by [50], who reported that plants have the capacity to adjust to a warming environment via physiological acclimation of respiration to warming. Strongest growth response of $P$. abies during the last century might be related to different disturbance history of stands, which may have affected the response to warming through the changing canopy structure [40]. Alternatively, species-related growth responses to climate were reported by several authors [39,51,52].

Although trees at high elevation are generally saturated with carbohydrates [53-57] found support for the carbohydrate limitation hypothesis in deciduous L. decidua. They determined that L. decidua augmented its growth as a response to the addition of $\mathrm{CO}_{2}$, indicating that this species is potentially carbon limited at treeline. Hence, the observed increase in BAI of L. decidua in this study indicates that this deciduous species benefited not only from climate warming, but probably also from effects of $\mathrm{CO}_{2}$ fertilization on growth [37].

At treeline, increase in BAI was higher than the calculated age/size trend in all species, which is attributable to intensive climate warming in recent decades, and highest sensitivity of tree growth to temperature occurred when approaching the upper limit of tree existence [4]. At the krummholz limit, however, only deciduous $L$. decidua showed an increase in BAI which exceeded the expected age/size trend. Missing growth response of evergreen conifers at the krummholz limit is most likely due to winter desiccation, i.e., damage to needles and branches caused by ice crystal abrasion of blowing snow and late winter water losses, which cannot be replaced because of frozen soil [58,59].

\section{Conclusions}

We found significant elevational and species-related trends in BAI of widespread coniferous species of the Eastern CEA, but no consistent growth response that is in parallel with the rapid rise of summer temperature in recent decades. Our results therefore revealed that although enhanced tree growth occurred at high elevation in response to climate warming, growth increase in the subalpine zone has declined in P. cembra and remained constant in P. abies and L. decidua over the last decades, despite the more intensified warming taking place since late 1970s. This finding indicates that tree growth response to climate warming is possibly nonlinear, and that the underlying ecological and physiological mechanisms, i.e., stand dynamics and climatic influences beyond the growing season, respectively, driving these temporal changes are not yet completely resolved. Our study thus highlights the importance of species- and stand-specific assessments to identify the influencing environmental factors of tree growth at high elevation. Such assessments are important because they help predict treeline dynamics and carbon sequestration under an increasingly warmer and drier climate.

Author Contributions: W.O. and G.W. conceived the study and W.O. supervised the research activities. U.B., V.G., J.G., A.H., H.K., and B.W. collected and analyzed the dendrochronological data. W.O., G.W., and W.K. interpreted and discussed the data. W.O. wrote the manuscript, and G.W. and W.K. provided editorial advice. All authors have read and agreed to the published version of the manuscript.

Funding: This research received no external funding.

Conflicts of Interest: The authors declare no conflict of interest.

\section{References}

1. Körner, C. A re-assessment of high elevation tree line positions and their explanation. Oecologia 1998, 115, 445-459. [PubMed] 
2. Esper, J.; Cook, E.R.; Schweingruber, F.H. Low-frequency signals in long tree-ring chronologies for reconstructing past temperature variability. Science 2002, 295, 2250-2253. [CrossRef] [PubMed]

3. Wieser, G.; Tausz, M. Trees at Their Upper Limit: Treelife Limitation at the Alpine Timberline. In Plant Ecophysiology; Springer: Berlin/Heidelberg, Germany, 2007; Volume 5.

4. Körner, C. Alpine Treelines. Funtional Ecology of the Global High Elevation Tree Limits; Springer: Basel, Switzerland, 2012.

5. Körner, C.; Paulsen, J. A world-wide study of high altitude treeline temperatures. J. Biogeogr. 2004, 31, 713-732. [CrossRef]

6. Rossi, S.; Deslauriers, A.; Gričar, J.; Seo, J.-W.; Rathgeber, C.B.K.; Anfodillo, T.; Morin, H.; Levanic, T.; Oven, P.; Jalkanen, R. Critical temperatures for xylogenesis in conifers of cold climates. Glob. Ecol. Biogeogr. 2008, 17, 696-707. [CrossRef]

7. Carrer, M.; Urbinati, C. Age-dependent tree ring growth responses to climate of Larix decidua and Pinus cembra in the Italian Alps. Ecology 2004, 85, 730-740. [CrossRef]

8. Oberhuber, W. Influence of climate on radial growth of Pinus cembra within the alpine timberline ecotone. Tree Physiol. 2004, 24, 291-301. [CrossRef]

9. IPCC. Contribution of Working Groups I, II and III to the Fifth Assessment Report of the Intergovernmental Panel on Climate Change. In Climate Change 2014: Synthesis Report; Pachauri, R.K., Meyer, L.A., Eds.; IPCC: Geneva, Switzerland, 2014.

10. Auer, I.; Böhm, R.; Jurkovic, A.; Lipa, W.; Orlik, A.; Potzmann, R.; Schöner, W.; Ungersböck, M.; Matulla, C.; Briffa, K.; et al. HISTALP-Historical instrumental climatological surface time series of the greater Alpine region 1760-2003. Int. J. Climatol. 2007, 27, 17-46. [CrossRef]

11. Gobiet, A.; Kotlarski, S.; Beniston, M.; Heinrich, G.; Rajczak, J.; Stoffel, M. 21st century climate change in the European Alps-A review. Sci. Total Environ. 2014, 493, 1138-1151. [CrossRef]

12. Büntgen, U.; Frank, D.; Wilson, R.; Carrer, M.; Urbinati, C. Testing for tree-ring divergence in the European Alps. Glob. Chang. Biol. 2008, 14, 2443-2453. [CrossRef]

13. St George, S.; Esper, J. Concord and discord among Northern Hemisphere paleotemperature reconstructions from tree rings. Quat. Sci. Rev. 2019, 203, 278-281. [CrossRef]

14. D'Arrigo, R.; Wilson, R.; Liepert, B.; Cherubini, P. On the 'divergence problem' in northern forests: A review of the tree ring evidence and possible causes. Glob. Planet. Chang. 2008, 60, 289-305. [CrossRef]

15. Oberhuber, W.; Kofler, W.; Pfeifer, K.; Seeber, A.; Gruber, A.; Wieser, G. Long-term changes in tree-ring-climate relationships at Mt. Patscherkofel (Tyrol, Austria) since the mid-1980s. Trees 2008, 22, 31-40. [CrossRef] [PubMed]

16. Cazzolla Gatti, R.; Callaghan, T.; Velichevskaya, A.; Dudko, A.; Fabbio, L.; Battipaglia, G.; Liang, J. Accelerating upward treeline shift in the Altai Mountains under last-century climate change. Sci. Rep. 2019, 9, 7678. [CrossRef] [PubMed]

17. Wieser, G.; Oberhuber, W.; Gruber, A. Effects of climate change at treeline: Lessons from space-for-time studies, manipulative experiments, and long-term observational records in the Central Austrian Alps. Forests 2019, 10, 508. [CrossRef]

18. Babst, F.; Bouriaud, O.; Alexander, R.; Trouet, V.; Frank, D. Toward consistent measurements of carbon accumulation: A multi-site assessment of biomass and basal area increment across Europe. Dendrochronologia 2014, 32, 153-161. [CrossRef]

19. Salzer, M.W.; Larson, E.R.; Bunn, A.G.; Hughes, M.K. Changing climate response in near-treeline bristlecone pine with elevation and aspect. Environ. Res. Lett. 2014, 9, 114007. [CrossRef]

20. Sullivan, P.F.; Ellison, S.B.Z.; McNown, R.W.; Brownlee, A.H.; Sveinbjoernsson, B. Evidence of soil nutrient availability as the proximate constraint on growth of treeline trees in northwest Alaska. Ecology 2015, 96, 716-727. [CrossRef]

21. Liang, E.; Leuschner, C.; Dulamsuren, C.; Wagner, B.; Hauck, M. Global warming related tree growth decline and mortality on the north-eastern Tibetan Plateau. Clim. Chang. 2016, 134, 163-176. [CrossRef]

22. Liu, B.; Wang, Y.; Zhu, H.; Liang, E.; Camarero, J.J. Topography and age mediate the growth responses of Smith fir to climate warming in the southeastern Tibetan Plateau. Int. J. Biometeorol. 2016, 60, 1577-1587. [CrossRef] 
23. Harris, I.C.; Jones, P.D. CRU TS4.01: Climatic Research Unit (CRU) Time-Series (TS) Version 4.01 of High-Resolution Gridded Data of Month-by-Month Variation in Climate (Jan. 1901-Dec. 2016); Centre for Environmental Data Analysis: Norwich, UK, 2017. [CrossRef]

24. Estrada, F.; Perron, P.; Martínez-López, B. Statistically derived contributions of diverse human influences to twentieth-century temperature changes. Nat. Geosci. 2013, 6, 1050-1055. [CrossRef]

25. Hegerl, G.C.; Brönnimann, S.; Schurer, A.; Cowan, T. The early 20th century warming: Anomalies, causes, and consequences. WIREs Clim. Chang. 2018, 9, e522. [CrossRef] [PubMed]

26. Leuschner, C.; Ellenberg, H. Ecology of Central European Forests. In Vegetation Ecology of Central Europe; Springer: Berlin/Heidelberg, Germany, 2017; Volume 1.

27. Tollmann, A. Geologie von Österreich Band 1. In Die Zentralalpen; Deuticke: Wien, Austria, 1977.

28. Holmes, R.L. Computer-assisted quality control in tree ring dating and measurement. Tree Ring Bull. 1983, $43,69-78$.

29. LeBlanc, D.C. Relationships between breast-height and whole-stem growth indices for red spruce on Whiteface mountain, New York. Can. J. For. Res. 1990, 20, 1399-1407. [CrossRef]

30. Biondi, F.; Qeadan, F. A theory-driven approach to tree-ring standardization: Defining the biological trend from expected basal area increment. Tree Ring Res. 2008, 64, 81-96. [CrossRef]

31. Peters, R.L.; Groenendijk, P.; Vlam, M.; Zuidema, P.A. Detecting long-term growth trends using tree rings: A critical evaluation of methods. Glob. Chang. Biol. 2015, 21, 2040-2054. [CrossRef]

32. Wieser, G.; Matyssek, R.; Luzian, R.; Zwerger, P.; Pindur, P.; Oberhuber, W.; Gruber, A. Effects of atmospheric and climate change at the timberline of the Central European Alps. Ann. For. Sci. 2009, 66, 402. [CrossRef]

33. Erb, K.H.; Kastner, T.; Luyssaert, S.; Houghton, R.A.; Kuemmerle, T.; Olofsson, P.; Haberl, H. Bias in the attribution of forest carbon sinks. Nat. Clim. Chang. 2013, 3, 854-856. [CrossRef]

34. Büntgen, U.; Frank, D.C.; Nievergelt, D.; Esper, J. Summer temperature variations in the European Alps, AD 755-2004. J. Clim. 2006, 19, 5606-5623. [CrossRef]

35. Carrer, M.; Nola, P.; Eduard, J.L.; Motta, R.; Urbinati, C. Regional variability of climate-growth relationships in Pinus cembra high elevation forests in the Alps. J. Ecol. 2007, 95, 1072-1083. [CrossRef]

36. Williams, A.P.; Allen, C.D.; Macalady, A.K.; Griffin, D.; Woodhouse, C.A.; Meko, D.M.; Swetnam, T.W.; Rauscher, S.A.; Seager, R.; Grissino-Mayer, H.D.; et al. Temperature as a potent driver of regional forest drought stress and tree mortality. Nat. Clim. Chang. 2013, 3, 292-297. [CrossRef]

37. Wieser, G.; Oberhuber, W.; Gruber, A.; Leo, M.; Matyssek, R.; Grams, T.E.E. Stable water use efficiency under climate change of three sympatric conifer species at the alpine treeline. Front. Plant Sci. 2016, 7, 799. [CrossRef] [PubMed]

38. Saulnier, M.; Edouard, J.L.; Corona, C.; Guibal, F. Climate/growth relationships in a Pinus cembra high-elevation network in the Southern French Alps. Ann. For. Sci. 2011, 68, 189-200. [CrossRef]

39. Babst, F.; Poulter, B.; Trouet, V.; Tan, K.; Neuwirth, B.; Wilson, R.J.S.; Carrer, M.; Grabner, M.; Tegel, W.; Levanič, T.; et al. Site- and species-specific responses of forest growth to climate across the European continent. Glob. Ecol. Biogeogr. 2013, 22, 706-717. [CrossRef]

40. Primicia, I.; Camarero, J.J.; Janda, P.; Čada, V.; Morrissey, R.C.; Trotsiuk, V.; Bače, R.; Teodosiu, M.; Svoboda, M. Age, competition, disturbance and elevation effects on tree and stand growth response of primary Picea abies forest to climate. For. Ecol. Manag. 2015, 354, 77-86. [CrossRef]

41. Szeicz, J.M.; MacDonald, G.M. Age dependent tree-ring growth response of subarctic white spruce to climate. Can. J. For. Res. 1994, 24, 120-132. [CrossRef]

42. Girardin, M.P.; Guo, X.J.; Bernier, P.Y.; Raulier, F.; Gauthier, S. Changes in growth of pristine boreal North American forests from 1950 to 2005 driven by landscape demographics and species traits. Biogeosciences 2012, 9, 2523-2536. [CrossRef]

43. Esper, J.; Niederer, R.; Bebi, P.; Frank, D. Climate signal age effects-Evidence from young and old trees in the Swiss Engadin. For. Ecol. Manag. 2008, 255, 3783-3789. [CrossRef]

44. Cherubini, P.; Dobbertin, M.; Innes, J.L. Potential sampling bias in long-term forest growth trends reconstructed from tree rings: A case study from the Italian Alps. For. Ecol. Manag. 1998, 109, 103-118. [CrossRef]

45. Brienen, R.J.W.; Gloor, E.; Zuidema, P.A. Detecting evidence for $\mathrm{CO}_{2}$ fertilization from tree ring studies: The potential role of sampling biases. Glob. Biogeochem. Cycles 2012, 26. [CrossRef] 
46. Nehrbass-Ahles, C.; Babst, F.; Klesse, S.; Nötzli, M.; Bouriaud, O.; Neukom, R.; Dobbertin, M.; Frank, D. The influence of sampling design on tree-ring-based quantification of forest growth. Glob. Chang. Biol. 2014, 20, 2867-2885. [CrossRef]

47. Bowman, D.M.J.S.; Brienen, R.J.W.; Gloor, E.; Phillips, O.L.; Prior, L.D. Detecting trends in tree growth: Not so simple. Trends Plant Sci. 2013, 18, 11-17. [CrossRef] [PubMed]

48. Duchesne, L.; Houle, D.; Ouimet, R.; Caldwell, L.; Gloor, M.; Brienen, R. Large apparent growth increase in boreal forests inferred from tree-rings are an artefact of sampling design. Sci. Rep. 2019, 9, 6832. [CrossRef] [PubMed]

49. Li, M.H.; Yang, J. Effects of microsite on growth of Pinus cembra in the subalpine zone of the Austrian Alps. Ann. For. Sci. 2004, 61, 319-325. [CrossRef]

50. Reich, P.B.; Sendall, K.M.; Stefanski, A.; Wei, X.; Rich, R.L.; Montgomery, R.A. Boreal and temperate trees show strong acclimation of respiration to warming. Nature 2016, 531, 633-636. [CrossRef]

51. Girardin, M.P.; Bouriaud, O.; Hogg, E.H.; Kurz, W.; Zimmermann, N.E.; Metsaranta, J.M.; Jong Rde Frank, D.C.; Esper, J.; Büntgen, U.; Guo, X.J.; et al. No growth stimulation of Canda's boreal forest under half-century of combined warming and $\mathrm{CO}_{2}$ fertilization. Proc. Natl. Acad. Sci. USA 2016, 113, E8406-E8414. [CrossRef] [PubMed]

52. Liang, P.; Wang, X.; Sun, H.; Fan, Y.; Wu, Y.; Lin, X.; Chang, J. Forest type and height are important in shaping the altitudinal change of radial growth response to climate change. Sci. Rep. 2019, 9, 1336. [CrossRef]

53. Hoch, G.; Körner, C. The carbon charging of pines at the climatic treeline: A global comparison. Oecologia 2003, 135, 10-21. [CrossRef]

54. Hoch, G.; Körner, C. Global patterns of mobile carbon stores in trees at the high-elevation treeline. Glob. Ecol. Biogeogr. 2012, 21, 861-871. [CrossRef]

55. Gruber, A.; Pirkebner, D.; Oberhuber, W.; Wieser, G. Spatial and seasonal variations in mobile carbohydrates in Pinus cembra in the timberline ecotone of the Central Austrian Alps. Eur. J. For. Res. 2011, 130, 173-179. [CrossRef]

56. Handa, I.T.; Körner, C.; Hättenschwiler, S. A test of the treeline carbon limitation hypothesis by in situ $\mathrm{CO}_{2}$ enrichment and defoliation. Ecology 2005, 86, 1288-1300. [CrossRef]

57. Dawes, M.A.; Hättenschwiler, S.; Bebi, P.; FHagedorn ITHanda CKörner, C. Rixen Species-specific tree growth responses to 9 years of $\mathrm{CO}_{2}$ enrichment at the alpine treeline. J. Ecol. 2011, 99, 383-394.

58. Tranquillini, W. Physiological Ecology of the Alpine Timberline. In Tree Existence in High Altitudes with Special Reference to the European Alps; Ecological Studies 31; Springer: Berlin/Heidelberg, Germany, 1979.

59. Hadley, J.L.; Smith, W.K. Wind effects on needles of timberline conifers: Seasonal influence of mortality. Ecology 1986, 67, 12-19. [CrossRef] 